\title{
Effects of Green Logistics Adoption on the Performance of Commercial State Corporations in Kenya
}

\author{
Viola Jemutai Rop*, Noor Shalle, Kennedy Kirima Nteere \\ School of Business, Jomo Kenyatta University of Agriculture and Technology, Nairobi, Kenya \\ Email address: \\ viorop@gmail.com (V. J. Rop), shalle60@hotmail.com (N. Shalle), kkirima@cuk.ac.ke (K. K. Nteere) \\ ${ }^{*}$ Corresponding author
}

\section{To cite this article:}

Viola Jemutai Rop, Noor Shalle, Kennedy Kirima Nteere. Effects of Green Logistics Adoption on the Performance of Commercial State Corporations in Kenya. Journal of Business and Economic Development. Vol. 6, No. 3, 2021, pp. 170-175. doi: 10.11648/j.jbed.20210603.16

Received: April 25, 2021; Accepted: May 13, 2021; Published: August 31, 2021

\begin{abstract}
The adoption of green logistics in commercial state establishments is an emerging phenomenon throughout the world. The purpose of this paper was to evaluate the influence of green purchasing practices on performance of state corporations in Kenya. Ten commercial state corporations in Kenya including Kenya Literature Bureau, Kenya Airport Authority, East African Portland Cement Company, Jomo Kenyatta Foundation, Kenya Broadcasting Corporations, Kenya Ordinance Factories Bureau, Kenya Railways Corporation, Kenya Seed Company, Chemelil Sugar Company and finally Kenya Electricity Generating Company were selected for this study. The study adopted a descriptive design and used a sample of 175 respondents from ten state corporations. The respondents were selected through stratified sampling. The primary data collection method applied in this study constituted questionnaires both open-ended and closed. Results revealed that; considering corporations use of green raw materials, the suppliers use of green purchasing and the use of recycling of products or materials technologically had a positive impact on the performance of public corporations in Kenya. Results also revealed that considering commercial cooperation's use of responsive packaging also had an influence.
\end{abstract}

Keywords: Green Purchasing, Performance, State Corporations, Stratified Sampling, Descriptive Research Design

\section{Introduction}

Environmental contamination presents an incredibly intricate issue and numerous environmental cognizant individuals are getting progressively mindful of this reality. The quantity of associations mulling over the incorporation of actions in favor of the environment into their key policies and everyday activities is constantly expanding. The universal progression of the economy has offered ascend to a tremendous utilization of products while globalization has prompted huge surges of merchandise everywhere in the world.

The making, transportation, stockpiling, and utilization of items have made huge environmental issues. Organizations, both state owned and private are requesting measures to strike down this danger. Thus, there has been piling pressure from the public on corporations to decrease the effects that their Logistics activities have on nature. Organizations have, in recent decades, made and received better arranged measures in line with the eventual benefits of nature, for example, planning for recyclability, utilization of sustainable power source, zero waste creation, and planning items that don't hurt the ecosystem [1].

Moving merchandise negatively affects the nearby air quality, produces noise pollution, prompts mishaps, and, in entirety, contributes to adverse climate effects [2]. These effect have compelled the expansion of consideration as of late, mostly on the grounds that expanding charges on effluence and enhancing street security have mitigated other environmental issues. With the Kyoto Agreement in function around the world, most nations have upheld the green enactment for organizations to put social duty regarding green item configuration, garbage removals and reverse Logistics streams including utilized items and assembling initiated squanders.

The emergence of Green logistics is important for organizations to maximize gains by minimizing damage to the environment [3]. In the United States of America for instance, Nike has a well-established sustainability system. Nike has a huge impact on people and resources around the 
globe [4]. The company heavily depends on fossil fuel and oil for materials, exposing them to carbon restrictions in the future. The major risk factors associated with Nike industries are toxic raw materials, waste products and their disposal. For the green initiative, Nike has created a program known as Nike's Reuse a shoe program where the company collects used tennis shoes. This shows they have a well-established reverse logistic system [5]. Further, they have a policy on factory emissions to minimize global warming by burning most of their wastes in an incinerator [6]. The Nike company encountered their first hurdle in the 90 s which made them better their policy on wages and legal age to work in their factories. This has shown how sustainable green logistics can positively impact performance with Nike though due to competition, the company could not diverge most of the information on how much performance was enhanced on this [7]. Chinese enterprises are among the most competitive enterprises. They have increased their green awareness and highlighted their exporting philosophies by pursuing international organizational standards. The enterprises have also implemented logistics practices so that they can offer the best supply to foreign enterprises [8]. Development of any logistics programs in China will depend on the willingness of managers at the topmost levels to commit with support from their subordinates [9]. Educating employees on management in logistics practices is a crucial step in implementing the logistics practices. Chinese enterprises have acknowledged the importance of logistics, but are lagging on the implementation due to the shortage in necessary tools, management skills and an economic justification [10]. High levels of awareness among Chinese enterprises has however not translated into resilient logistics practice adoption.

\section{Literature Review}

The Logistics Management Theory was pioneered with the intention to satisfy consumers and other parties interested in the merchandise [11]. The theory is based on all the procedures involved in the manufacturing, processing and delivery while focusing on lowering costs and tied up capital together with minimal environmental penalties [12]. This operation's credibility is centered around the effectiveness of the system scheme leading to this kind of logistics process. Logistics management is the procurement component that deals with planning and implementing, reverse and forward flow as well storing goods with an aim of meeting customer's requirements. Logistics management covers several activities among which customer services ranks highest, closely followed by sourcing and planning of production. To some degree, logistics management is integrated into all levels of planning. Scheduling, assembling and packing of goods is also under logistics management [13]. It is the bridge that connects all these functions to marketing, finance, and Information technology. Logistics management is an assimilating utility involved with the coordination and optimization of all things logistics. The variable "reverse logistics" was supported through Logistics management theory since costs associated with delays when returning goods such as damaged reputation and stock holding costs would be controlled.

Resources are what a business needs to increase its gains or production. They can be tangible or intangible. Technology is a resource as well as raw materials needed for the production of goods. The theory helps comprehend the reason for distinctive performance variation of companies in the same industry over time. Conversely, it helps understand why some firms persistently perform better than others. The value chain concept in an attempt to explain how firms attain a competitive advantage over others [14]. The ResourceBased View Theory, on the other hand, evidences that competitive advantage is a result of internal rare resources and capabilities.

The resources may include the assets, capabilities, organizational processes, or information. The theoretical supports suggest the main organization has full control over resources that need to be harnessed to enable them to contribute to the organization's competitive advantage. The theory links with these research variables, which seeks to understand how the adoption of a green supply chain may influence an organization's performance. A resource is said to be rare if the number of firms desired to create impeccable competition surpasses the number of firms in possession of the resource among the competitive arena [15]. In this context, factories that have embraced ecologically unique designs could be better positioned than others and give insight into how the adoption of Eco-design changes in a firm's performance [16].

In the resource-based view theory, allocating resources to activities that do not directly translate into profits leads to opportunity costs. Competences are strategic assets that firms have to achieve long term returns [17].

Green products have been evidenced to cost more than the non-green [18]. This ensures customer loyalty by creating a positive impression on the mind of their consumers after the company adopts green procurement in government corporations. A firm can also utilize the resources to its advantage and gain a competitive advantage.

Commonly referred to environmentally preferable purchasing. It is the adoption of products or services that have a less detrimental impact on human life and the environment. Corporations have an obligation to implement policies demanding that suppliers meet certain environmental calibers [19]. Firms take measures to ensure that their employees are aware and they understand the importance of adopting green logistics. Collaboration based activities are a common way of achieving this. The activities include trainings, information sharing on the environment and joint researches [20].

Application of GLP necessitates that companies engage in practices that are in line with the guidelines of supply chain management. Green practices in organizations are identified as systems of quality management. The environmental performance of accompany heavily depends on internal management. 
The quality management is the lubricant to the employment of Global supply chain management (GSCM) in state corporations. Their work suggests that organizations can develop their green practice under rigorous quality control [21]. Quality management programs are put in place to create a platform where firms can learn from previous experiences and are able to determine the outcome of a new green practice. "Green" certificates are availed to companies as an approval of their working standards meeting the set international standards. ISO 140011:2015 certification confirms that the firm and its products have an effective environmental management system.

The priorities of the consumer and the supplier should be consistent as it is paramount for effective adoption of green logistics. The supply chain strategy and the firm's competitive advantages must also be in synchrony [22]. For the most efficient design, firms exercise their service requirement to meet the consumers need this enable them to outperform their competitors as they shift their focus to matching their competitive advantages to the desires of consumers [23].

Green logistics practices are gaining status across many sectors in the world, as well as various government corporations. The adoption of green procurement has been necessitated by the urge to become environmentally sustainable and enhance performance while aiming at gaining a competitive advantage. There has been a rise in the environment pollution cases that calls for protection, hence the need to enact green practices. By doing this, organizations are directly dealing with the issue of sustainability in the supply chain. There is increased pressure for these organizations to carry out their daily happenings in a manner that harms the environment less. There is no change in policies encompassing delivery of products allowing operators in logistics to use advantages of every mode of transportation in a more rational way, the traffic of heavy merchandise will solely increase by nearly $50 \%$ increasing the carbon dioxide emissions [24].

\section{Methodology}

The overall strategy used in this study was a descriptive research design. Descriptive design is the ideal design because it reports things as they are. To determine the most accurate research design, one should consider the priorities and determine the data needed before decided how to collect that data [25]. The descriptive design was employed to get clear data from the respondents. Stratified sampling was used to select 175 respondents into the sample.

A closed-ended and open-ended questionnaire was administered to the respondents.

The primary tool of data collection was the questionnaires. These questionnaires were used to seek crucial information on the effects of green logistics from the target population. The questionnaire included open and closed-ended questions to enable effective data collection. Open ended questions allowed the respondents to give their opinions and give a sense of the level of understanding they have on the issue under investigation. The questionnaire was divided into various sections in line with the objectives of this research. Close-ended questions allowed for statistical analysis, easy coding, quicker responses, and direct research towards a distinctive conclusion. Questionnaires were distributed to thirty-five employees of the 10 commercial corporations that were selected. These were sent to the logistic manager, supply chain manager, finance manager, and the Chief Executive Officer.

The data collected was screened to identify omissions and remove unanswered questions. The data that was collected was used to obtained qualitative and quantitative analysis. For quantitative data analysis, coding and entry was done in an electronic spreadsheet with the aid of Statistical Package for Social Sciences (SPSS). The relationship among the study's independent variables and dependent variables as set out in the objectives was determined by running Pearson's correlations coefficients. After analysis, the data representation was done through use of charts, graphs and tables. The responses were summarized using descriptive statistics, mainly frequencies, percentages, and mean in order to find out the effect of reverse logistics on the performance of commercial state corporations in Kenya and give an answer to the objective that is to determine the extent at which eco-design affect the performance of commercial state corporations in Kenya.

The extraction of useful information from collected data is known as data analysis. The quantitative part of the data was analyzed using descriptive statistics. These simple measures describe the basic components of a research. They include; frequency calculation and distribution tables, mean, measures of standard deviation and relativeness.

Inferential statistics give a measure of what cannot be seen. They deduce underlying distributions and give measures of probable scenarios. The study employed regression model to establish connections between the variables under investigation. The Pearson's correlation coefficient was used to predict how employing green logistics practices in an organization correlates to the performance of the organization. A linear regression model was adopted for the study.

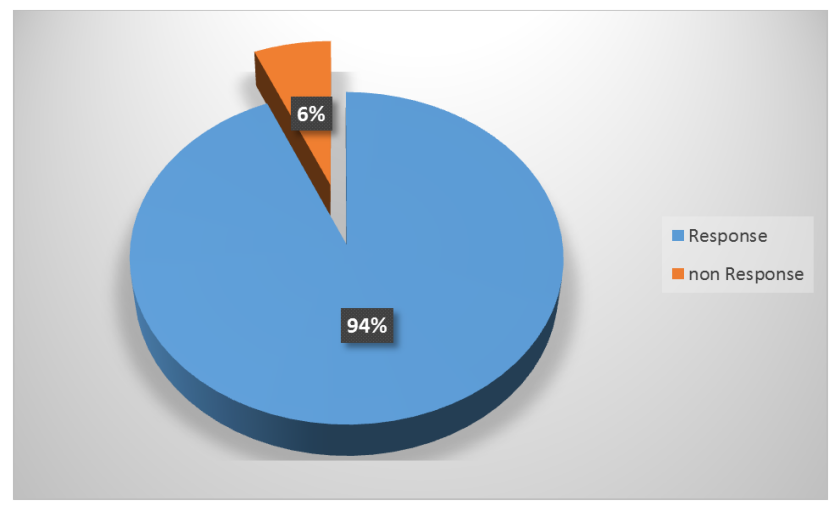

Figure 1. Response Rate. 


\section{Findings}

175 questionnaires were filled by the respondents, which represented $94 \%$ of the target sample respondents. Scholars hold differing positions on the acceptable response rate; some believe $50 \%$ is adequate for analysis while others submit that a response rate of $60 \%$ is acceptable benchmark for analysis [26]. In view of this, the response rate of this study was good.

The results presented in the figure 2 reveal that $50.3 \%$ of the institutions were fully publicly funded, $25.7 \%$ of the institutions were partially publicly funded and $24 \%$ were not publicly funded.

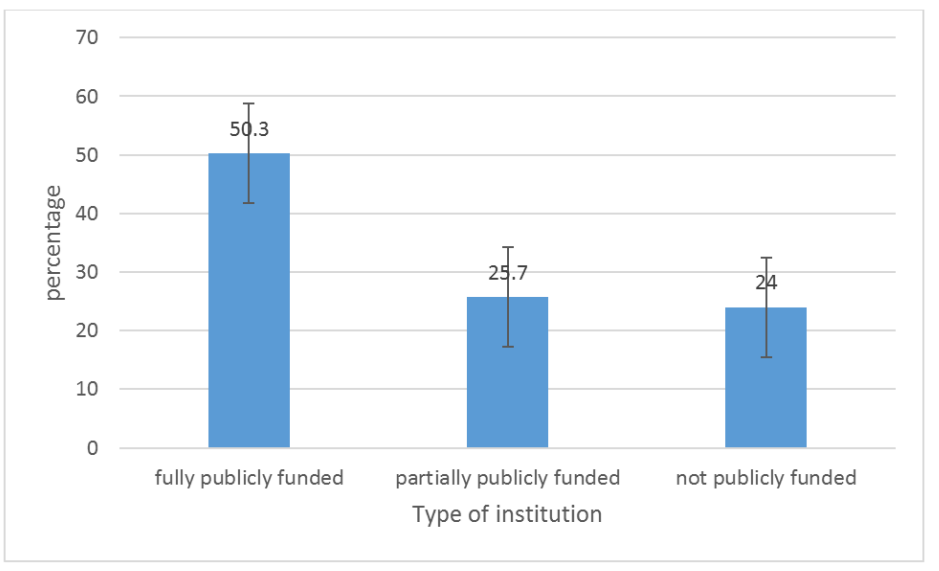

Figure 2. Descriptive statistics of the institutions.

Regression analysis was also conducted. This helped in determining how the independent variables (reverse logistics practices, eco design practices, green purchasing practices and responsible packaging practices) affected the dependent variable (performance). At the end of the analysis, an
ANOVA, model summary and beta coefficients were produced. Before any other inferential statistics are conducted, an ANOVA should be carried out. It helps in determining whether the overall model is significant. Table shows the results in this regard.

Table 1. ANOVA Test.

\begin{tabular}{lllllll}
\hline ANOVA $^{\mathbf{a}}$ & & & & & \\
\hline Model & & Sum of Squares & df & Mean Square & F & Sig. \\
\hline \multirow{3}{*}{1} & Regression & 26.254 & 4 & 6.564 & 119.737 & $.000^{\mathrm{b}}$ \\
& Residual & 9.209 & 168 & .055 & & \\
\hline & Total & 35.464 & 172 & & & \\
\hline
\end{tabular}

The researcher combined the entire study variable after which an Analysis of Variance was conducted. Table 1 shows the findings the $\mathrm{F}$ calculated at 5\% Level of significance was 119.737 Since F calculated had a corresponding probability value of 0.000 which was less than 0.05 ) this shows that the overall model was significant. The ANOVA results reveal that there is a significant influence of green purchasing practices on performance. After determining the overall fitness of the model, a model summary was extracted showing the values of $\mathrm{R}$ square. The table below shows the results obtained.

Table 2. Model Summary.

\begin{tabular}{lllll}
\hline Model Summary & & & \\
\hline Model & R & R Square & Adjusted R Square & Std. Error of the Estimate \\
\hline 1 & $.860^{\mathrm{a}}$ & .740 & .734 & .23413 \\
\hline
\end{tabular}

According to the table, the model explain $74 \%$ of the performance of state corporations in Kenya. This was represented by the $\mathrm{R}^{2}$. This therefore means that the green purchasing practices contribute $86 \%$ to the performance of state corporations in Kenya while other aspects not studied in this research contribute $14 \%$ of performance of state corporations in Kenya. The beta coefficient of the model show the extent of the influence of the independent study variable and the dependent one. Table shows the beta coefficients of the model.

Table 3. Regression Coefficients.

\begin{tabular}{|c|c|c|c|c|c|c|}
\hline \multicolumn{7}{|c|}{ Coefficients $^{\mathrm{a}}$} \\
\hline \multirow{2}{*}{\multicolumn{2}{|c|}{ Model }} & \multicolumn{2}{|c|}{ Unstandardized Coefficients } & \multirow{2}{*}{$\begin{array}{l}\text { Standardized Coefficients } \\
\text { Beta }\end{array}$} & \multirow{2}{*}{$\mathbf{t}$} & \multirow{2}{*}{ Sig. } \\
\hline & & B & Std. Error & & & \\
\hline \multirow{2}{*}{1} & (Constant) & .899 & .227 & & 3.959 & .000 \\
\hline & Green purchasing practices & .322 & .065 & .216 & 4.975 & .000 \\
\hline
\end{tabular}

a. Dependent Variable: Performance 
A regression model depicted in the table above is represented by the equation:

$$
\mathrm{Y}=0.899+0.322 \mathrm{X}_{1}
$$

The results also show that the performance of state corporations is positively and significantly related to green purchasing practices. This is indicated by a regression coefficient of 0.322 , which is a positive coefficient and a p-value of 0.000 less than 0.05 showing the significance of the relationship. Thus, a unit increase in green purchasing practices would lead to a 0.322 times increase in the performance.

\section{Conclusions}

The results showed a positive and significant relationship between green purchasing practices and performance. This indicates that Performance of state corporations in Kenya is positively influenced by increased green purchasing practices.

There is a strong relationship between green purchasing practices and performance of Performance of state corporations in Kenya. Among the aspects of green purchasing that were widely practised in the processing sector include; cooperation with suppliers for eco-design of inputs, cooperation with suppliers for environmental objectives, reduced purchase of hazardous materials, reduced purchase of items to dispose of, organizations carry out environmental audits for supplier's internal management and conduct of environmental awareness seminars. The study therefore concluded that to enhance firms' performance it is imperative for manufacturing firms to invest heavily in green purchasing practices with respect to green supply chain management practices.

The study established that better eco design practices lead to improvement of environmental performance and firm performance through reducing pollution, decreasing costs and improving credibility and reputation while also contributing to the development of valuable capabilities, which increase the competitive advantage of the firm. Hence, support the argument that environmental pro-activeness has a positive impact on performance. It is recommended that manufacturing firms should fully adopt and implement green purchasing practice in compliance with all applicable legislations as a complement.

\section{References}

[1] Aaronson\& Huge Brodin (2006), the environmental impact of changing logistics structure.

[2] Amemba, C. S., Nyaboke, P. G., Osoro, A. \& Mburu, N. (2013). Elements of Green Supply Chain Management. European Journal of Business and Management. 5 (12) 51-61.

[3] Azevedo, S. G., Carvalho, H., \& Cruz Machado, V. (2011). The influence of green practices on supply chain performance: a case study approach. Transportation Research Part E: Logistics and Transportation Review, 47 (6), 850-871.
[4] Beyene, Z. (2015). Green supply chain management practices in Ethiopian tannery industry. International Research Journal of Engineering and Technology (IRJET), 2 (7), 587-598.

[5] Brammer, S., \& Walker, H. (2011). Sustainable Procurement Practice in the Public.

[6] Browne and Allen (2015) in their study on the environmental conservation.

[7] Chimwani, B. I., Iravo, M. A., \&Tirimba, O. I. (2014). Factors influencing green logistics performance in the Kenyan Public Sector: Case Study of the State Law Office. International Journal of Innovation and Applied Studies, 9 (4), 1626.

[8] Coltman, T. R., Devinney, T. M., \& Midgley, D. F., (2009). Green logistics Management \& Corporation performance, Faculty \& Research Working Paper, The Business School for the World, INSTEAD Printers, France.

[9] Contributions to New Product Advantage: Substitution and Configuration Options.

[10] Cooper, D. R., \& Schindler, P. S. (2003), "Business Research Methods", (8th edition). USA: McGraw-Hill.

[11] Cooper, D. R., \& Schindler, P. S. (2006), and "Business Research Methods" (9th edition), USA: McGraw-Hill.

[12] Ghauri and Gronhaug (2005) assert that in descriptive design, the problem is structured and well understood.

[13] Journal of Product Innovation Management, 30, 1-17.

[14] Lawson, B., Tyler, B. B. \& Potter, A. (2014). Strategic Suppliers' Technical.

[15] Lyons, K. \& Farrighton, B. (2012). Purchasing and supply management (8th edition). Great Britain. Pearson education hall.

[16] Mugenda, O. M \& Mugenda A. G (2003): Research Methods, Quantitative and Qualitative approaches, Acts Press, Nairobi.

[17] Nderitu, K. M \& Ngugi, k, (2014) Effects of Green procurement practices on an organization performance.

[18] Ngugi \& Nderitu, (2014) G. K. (2014). Determinants of adoption of green procurement in the public sector: A case study of Kenya Pipeline Company. International Journal of Social Sciences and Entrepreneurship, 1 (11), 351-372.

[19] Rodrigues, Slack and Comtois (2010). The Geography of Logistics systems.

[20] Sector: An International Comparative Study. International Journal of Operations and Production Management, 31 (4), $452-476$.

[21] Totenberg and Witt struck, 2012, Sustainable of supply chain management.

[22] Hughes, P. W., \& Laryea, D. S. (2013). Organizing for Sustainable Procurement: Theories, Institutions and Practice. Design and Management of Sustainable Built Environments. Springer, London, 385-396.

[23] Hussein, R. I., \& Shale, N. I. (2014). Effects of Sustainable Procurement Practices on Organizational Performance In Manufacturing Sector In Kenya: A Case of Unilever Kenya Limited. European Journal of Business Management, 1 (11), $1-14$. 
[24] Islam, M. M., Turki, A., Murad, M. W., \& Karim, A. (2017). Do Sustainable Procurement Practices Improve Organizational Performance? Sustainability, 9 (12), 2281. https://doi.org/10.3390/su9122281.

[25] Kenya Association of Manufacturers (KAM). (2018). Food and Bevarages. Retrieved July 12, 2018, from http://kam.co.ke/sectors/.
[26] Kenya Revenue Authority (KRA). (2018). Food and Other Manufacturers. Retrieved July 12, 2018, from http://www.revenue.go.ke/index.php/food-and-othermanufacturer. 